
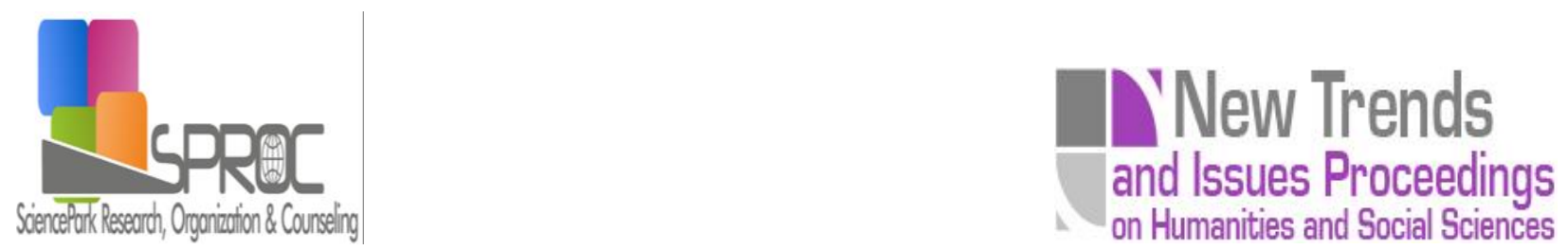

ISSN:2421-8030

www.prosoc.eu

\title{
A child with Down syndrome - Challenge for families, kindergartens and schools
}

Marina Duranovic *

Irena Klasnic

Valentina Opic

Suggested Citation:

New Trends and Issues Proceedings on Humanities and Social Sciences.

University of Zagreb,

Abstract

Marina Duranovic 
1. Who are children with Down syndrome?

2. A child with Down syndrome in family 
4. The objective of the case studies

complex dynamic interactions taking place in a unique way

\subsection{Case Study - Ivana}


4.2 Case Study-Peter 


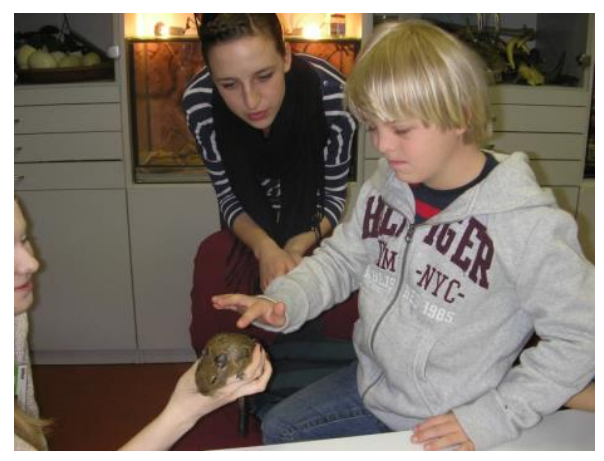

Figure 3. Peter at the zoo

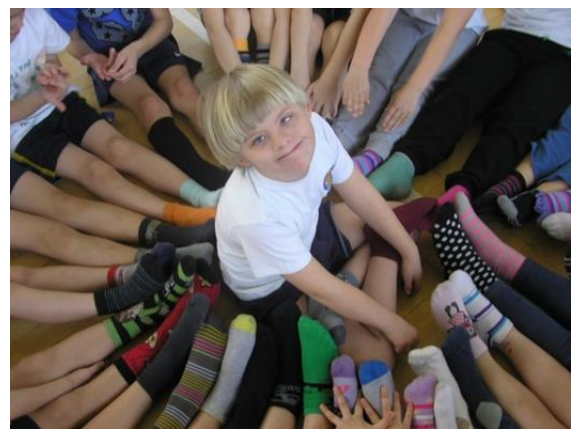

Figure 4. Peter in class on the World Day of People with Down Syndrome

\section{Conclusion}




\section{References}

\section{Sindrom Down}

Disorders, 34

Journal of Autism and Developmental

Developmental Psychology, 20

British Journal of

Journal of Intellectual Disability Research, 50

Developmental Disorders, 43

Journal of Autism and

Hrvatska revija za rehabilitacijska istrazivanja, 49

Metode istrazivanja u obrazovanju.

Practice, 4 ,

Down's Syndrome, Research and

Journal of Child Psychology \& Psychiatry \& Allied Disciplines 33

Journal of Intellectual Disability Research, 50

Hrvatska revija za rehabilitacijska istrazivanja, 49,

Research, 41

Journal of Leisure

Early Education and Development, 11 ,

Infants and Young Children, 21,

Intellectual and Developmental Disabilities, 45

emocionalnog razvoja.

Dijete s posebnim potrebama: poticanje intelektualnog $i$

Developmental Disorders, 40

Journal of Autism and 
Strategije kvalitativnih istrazivanja u primijenjenim drustvenim znanostima

Parenting, Science and Practice, 1

Journal of Intellectual Disability Research, 58

Downov sindrom u obitelji: priruCnik za roditelje i struCnjake.

istrazivanja, 50

Hrvatska revija za rehabilitacijska

Obitelji s kroniCno bolesnom djecom.

Journal of Child Psihology and Psychiatry, 44

retardacija:Biologijske osnove, klasifikacija i mentalni-zdravstveni problemi.

Mentalna

Djeca s posebnim potrebama.

Children's understanding of disability.

Rad s uCenicima s teskocama u razvoju u osnovnoj skoli.

British Journal of Special Education, 38

Research in Developmental Disabilities, 21

Razvoj govora i prevencija govornih poremecaja u djece.

47,

Journal of Intellectual Disability Research,

Disabilities, 17

Journal of Applied Research in Intellectual

Child \& Family Behavior Therapy, 19

Journal of Autism and Developmental Disorders, 36

Journal of Intellectual Disability Research, 51

Zivot i skola, 56

Poticanje razvoja pozitivne slike o sebi kod osoba s mentalnom retardacijom.

Infant Mental Health Journal, 29 


\section{Psihologija obrazovanja.}

Down sindrom: vodiC za roditelje i struCnjake.

Journal of Child Psychology and Psychiatry, 37

Downov sindrom-iskustva i spoznaje

Djeca s posebnim potrebama u vrticu i nizim razredima osnovne skole.

Drustvena istrazivanja, 22 